\title{
Pengaruh Persepsi dan Pengetahuan Akuntansi Pelaku Usaha Mikro Kecil dan Menengah Terhadap Penggunaan Informasi Akuntansi
}

\author{
Ni Made Intan Priliandani, Putu Dian Pradnyanitasari, Komang Adi Kurniawan \\ Universitas Warmadewa \\ intanpriliandani88@gmail.com, dianpradnya@gmail.com, komangadikurniawan@gmail.com
}

\begin{abstract}
Abstrak
Tujuan penelitian ini adalah untuk menganalisis persepsi pemilik pelaku UMKM terhadap penggunaan informasi akuntansi dan untuk menganalisis pengaruh pengetahuan akuntansi pelaku UMKM terhadap penggunaan informasi akuntansi. Penelitian ini diharapkan mampu memberikan pertimbangan bagi Pelaku UMKM di daerah Gianyar bahwa dengan pengetahuan dan pengalaman yang cukup mengenai akuntansi akan mampu menggunakan informasi akuntansi dengan baik serta mampu menghasilkan laporan keuangan perusahaan sehingga catatan atas keuangan perusahaan akan tercatat dengan baik. Populasi dalam penelitian ini adalah seluruh pelaku UMKM di Kabupaten Gianyar yang usahanya berada pada sektor perdagangan yang berjumlah 17.143 pedagang. Sampel dalam penelitian ini diambil dengan menggunakan rumus Slovin, tehnik penentuan sampelnya dengan cara simple random sampling sehingga sampel berjumlah 100 pedagang. Untuk menjawab Hipotesis dalam penelitian ini tehnik analisis data yang digunakan adalah dengan menggunakan regresi linear berganda. Hasil penelitian ini adalah persepsi pemilik dan pengetahuan akuntansi berpengaruh positif terhadap penggunaan informasi akntansi.
\end{abstract}

Kata Kunci: Persepsi Pemilik, Pengetahuan Akuntansi, dan Penggunaan Informasi Akuntansi

\begin{abstract}
The purpose of this study is to analyze the perceptions of owners of MSME actors on the use of accounting information and to analyze the influence of MSME accounting knowledge on the use of accounting information. This research is expected to be able to give consideration to SMEs in the Gianyar area that with sufficient knowledge and experience regarding accounting will be able to use accounting information well and be able to produce company financial reports so that the notes on the company's finances will be recorded properly. The population in this study were all SMEs in Gianyar Regency whose businesses were in the trade sector which amounted to 17,143 traders. The sample in this study was taken using the Slovin formula, the technique of determining the sample by simple random sampling so that the sample numbered 100 traders. To answer the hypothesis in this study the data analysis technique used is to use multiple linear regression. The results of this study are the perceptions of owners and accounting knowledge have a positive effect on the use of accounting information.
\end{abstract}

Keywords: Perception, Accounting Knowledge, and Use of Accounting Information

\section{Pendahuluan}

Usaha mikro, kecil, dan menengah (UMKM) adalah sebuah usaha yang bergerak diberbagai bidang usaha diantara adalah usaha perdagangan, usaha pertanian, usaha industri, usaha jasa, dan lain-lain. UMKM adalah salah satu cara untuk dapat mengurangi angka kemiskinan dan pengangguran. Pemerintah Indonesia memberikan perhatian yang tinggi atas 67 | Jurnal Akuntansi, Ekonomi dan Manajemen Bisnis keberadaan para pelaku UMKM tersebut hal ini karena UMKM dapat menyangga perekonomian rakyat kecil. UMKM dapat memberikan dampak secara langsung terhadap kehidupan masyarakat di sektor bawah. Peran UMKM dalam perekonomian masyarakat kecil adalah menjadi sarana untuk mengentaskan masyarakat dari jurang kemiskinan, sarana untuk meratakan tingkat perekonomian rakyat kecil, memberikan pemasukan 
devisa bagi negara. UMKM juga mendapat perhatian lebih dari pemerintah, karena keberhasilan UMKM memiliki manfaat yang besar khususnya untuk perekonomian Indonesia yaitu dapat membantu masyarakat pelaku UMKM lebih mandiri, membuat masyarakat lebih aktif dan kreatif dalam berpikir ideide terbaru untuk pengembangan usahanya.

UMKM memiliki kendala atau tantangan yang dihadapi pelaku UMKM yaitu terkait dengan pengelolaan dana dan penyusunan laporan keuangannya. Pengelolaan dana yang baik merupakan faktor penting dalam keberhasilan UMKM. UMKM memiliki kelemahan untuk penyusunan laporan keuangan karena rendahnya pendidikan, kurangnya pemahaman terhadap Standar Akuntansi Keuangan (SAK), dan pelatihan penyusunan laporan keuangan. Keterbatasan pengetahuan tentang pembukuan akuntansi, rumitnya proses akuntansi, dan anggapan pelaku UMKM bahwa laporan keuangan bukanlah hal yang penting bagi pelaku UMKM.

Pelaku UMKM memerlukan bantuan modal, modal yang disalurkan bagi pelaku UMKM seharusnya diberikan kredit khusus dengan mempermudah syaratsyarat sehingga tidak memberatkan pelaku UMKM. Peningkatan permodalan bagi pelaku UMKM dapat berupa peningkatan permodalan dari sektor financial formal ataupun sektor financial informal, yaitu perlindungan usaha baik itu usaha yang tergolong tradisional ekonomi rendah dan usaha tinggi harus mendapatkan perlindungan dari pemerintah baik dari segi Undang-undang dan peraturan pemerintah. Pengembangan kemitraan yaitu saling membantu dengan sesama pelaku UMKM baik dari segi pangsa pasar dalam negeri maupun pasar luar negeri. Pelatihan bagi pelaku UMKM dari pemerintah juga perlu dilakukan berupa pelatihan kewirausahaan, manajmen, administrasi dan pengetahuan tentang akuntansi dalam pembuatan laporan keuangan sehingga nantinya pelaku usaha dapat mengelompokkan labanya dengan benar. Adanya Laporan keuangan yang sudah tersusun dengan baik tentu saja akan membantu pelaku UMKM dalam memperoleh informasi akuntansi mengenai perusahaan dan laba perusahaan sehingga membantu pelaku UMKM dalam pengambilan keputusan untuk keberlangsungan hidup perusahaaan.

Penelitian yang dilakukan oleh Kurniawansyah (2016) yang menyatakan bahwa pencatatan akuntansi sulit dilakukan karena terbatasnya pengetahuan dan pemahaman pelaku UMKM, kebutuhan akan penyelenggaraan catatan akuntansi dianggap hanya membuang waktu dan biaya. Kendala utama pelaku UMKM dalam pembuatan pencatatan akuntansi adalah kurangnya tingkat pengetahuan dan dan pemahaman akan akuntansi, serti persepsi pelaku UMKM akan pembuatan catatan akuntansi nantinya akan menyita waktu dan biaya yang menyebabkan pelaku UMKM enggan untuk membuatan catatan akuntansi perusahaannya. Catatan atas akuntansi perusahaan ini nantinya akan menghasilkan laporan keuangan sehingga mampu membantu pelaku UMKM dalam pengambilan keputusan untuk keberlangsungan hidup suatu perusahaan.

Penelitian ini dilakukan di Kabupaten Gianyar alasannya adalah Gianyar merupakan daerah dengan banyaknya pelaku UMKM yang berkecimpung di bidang seni terlihat dari sekitar 65-70 persen dari total ekspor hasil industry kecil dan kerajinan rumah tangga di Pulau Dewata berasal dari Kabupaten Gianyar.

Berdasarkan latar belakang tersebut, maka peneliti merumuskan masalah mengenai penelitian yang dilakukan dengan menyajikan perumusan masalah dengan pertanyaan:

1. Apakah Persepsi Pelaku UMKM berpengaruh terhadap Penggunaan Informasi Akuntansi

2. Apakah Pengetahuan Akuntansi Pelaku UMKM berpengaruh terhadap Penggunaan Informasi Akuntansi

\section{Kajian Pustaka \\ 1. Konsep UMKM}

Pengertian UMKM di Indonesia di atur dalam Undang-undang Republik Indonesia No. 20 Tahun 2008 tentang UMKM pada pasal 1 dari UU tersebut menyatakan bahwa usaha mikro adalah usaha produktif milik orang perorangan atau badan usaha perorangan yang memiliki kriteria usaha mikro sebagaiman diatur dalam UU tersebut. Usaha kecil adalah usaha ekonomi produktif yang berdiri sendiri yang dilakukan oleh orang perorangan atau badan usaha yang bukan merupakan anak perusahaan atau bukan anak cabang yang dimiliki, dukuasai atau menjadi bagian, baik langsung maupun tidak langsung, dari usaha menengah atau usaha besar yang memenuhi kriteria usaha kecil sebagaimana dimaksudkan dalam UU tersebut. UMKM adalah nilai kekayaan bersih atau nilai aset tidak termasuk tanah dan bangunan tempat usaha, atau hasil penjualan tahunan, dengan kriteria sebagai berikut:

a. Usaha mikro adalah unit usaha yang memiliki aset paling banyak Rp50 juta tidak termasuk tanah dan bangunan tempat usaha dengan penjualan tahunana paling besar Rp300 juta.

b. Usaha kecil dengan nilai aset lebih dari Rp50 juta sampai dengan paling banyak Rp500 juta tidak termasuk tanah dan bangunan tampat usaha memiliki hasil penjualan tahunan lebih dari Rp300 juta hingga maksimum Rp. 2.5 milyar

c. Usaha menengah adalah perusahaan dengan nilai kekayaan bersih lebih dari Rp. 500 juta hingga paling banyak Rp100 milyar hasil penjualan tahunan diatas Rp2,5 milyar sampai paling tinggi Rp50 milyar.

Selain dengan menggunakan nilai moneter sebagai kriteria, sejumlah lembaga pemerintah seperti Departemen Perindustrian dan Badan Pusat Statistik (BPS), selama ini juga menggunakan jumlah pekerja sebagai ukuran untuk membedakan skala usaha antara 68 | Jurnal Akuntansi, Ekonomi dan Manajemen Bisnis | Vol. 8 No.1, July 2020, 67-73 | E-ISSN: 2548-9836 
usaha mikro, usaha kecil, usaha menengah dan usaha besar.

a. Usaha Mikro adalah unit usaha dengan jumlah pekerja tetap hingga 4 orang

b. Usaha Kecil antara 5 sampai 19 pekerja

c. Usaha menengah dari 20 sampai dengan 99 orang

d. Usaha besar dengan jumlah pekerja di atas 99 orang

\section{Persepsi}

Persepsi adalah suatu proses internal yang memungkinkan untuk memilih, mengorganisasikan serta menafsirkan rangsangan dari lingkungan sehingga proses tersebut dapat mempengaruhi perilaku (Mulyana, 2001). Pemilik adalah individu atau sekelompok orang yang memiliki ide untuk memulai suatu bisnis dengan mengorganisasikan, mengelola, dan mengasumsikan risiko suatu bisnis yang dihadapi mulai dari permulaan bisnis (Madura, 2001). Persepsi pemilik merupakan proses yang dialami oleh individu atau sekelompok pebisnis dalam menafsirkan rangsangan dan reaksi yang diperoleh untuk dapat memahami lingkungan suatu usaha.

\section{Pengetahuan Akuntansi}

Pengetahuan merupakan persepsi jelas tentang akan apa yang dipandang sebagai fakta, kebenaran, atau kewajiban, informasi atau pelajaran yang dipelihara dan diteruskan oleh peradaban. Akuntansi adalah proses pencatatan, pengelompokan dan pengikhtisaran kejadian-kejadian ekonomi dalam bentuk yang teratur dan logis dengan tujuan menyajikan informasi keuangan yang dibutuhkan untuk pengambilan keputusan (Belkaoui, 2000). Pengetahuan akuntansi adalah suatu pemahaman yang jelas akan apa yang dipandang sebagai fakta, kebenaran atau informasi mengenai proses pencatatan, pengelompokan, dan pengikhtisaran kejadian-kejadian ekonomi dalam bentuk yang teratur dan logis dengan tujuan menyajikan informasi keuangan yang dibutuhkan untuk pengambilan keputusan.

\section{Penggunaan Informasi Akuntansi}

Informasi akuntansi merupakan akuntansi sebagai informasi kuantitatif tentang entitas ekonomi yang bermanfaat untuk pengambilan keputusan ekonomi dalam menentukan pilihan-pilihan diantara alternatif-alternatif tindakan (Belkaoui 2000). Selanjutnya penggunaan informasi akuntansi merupakan proses, cara, pembuatan informasi akuntansi untuk pengambilan keputusan ekonomi dalam menentukan pilihan-pilihan diantara alternatif tindakan, untuk perencanaan strategis, pengawasan manajemen dan pengawasan operasional.

\section{Hubungan Persepsi Pelaku UMKM terhadap Penggunaan Informasi Akuntansi}

Persepsi pemilik merupakan proses yang dialami oleh individu atau sekelompok pebisnis dalam menafsirkan rangsangan dan reaksi yang diperoleh untuk dapat memahami lingkungan suatu usaha. Penggunaan Informasi Akuntansi merupakan proses, cara, pembuatan informasi akuntansi untuk pengambilan keputusan ekonomi dalam menentukan pilihan-pilihan diantara alternatif tindakan, untuk perencanaan strategis, pengawasan manajmen dan pengawasan operasional. Persepsi pemilik yang tinggi akan menyebabkan penggunaan informasi akuntansi juga akan meningkat hal ini disebabkan karena pelaku umum dengan persepsi tinggi berarti pelaku UMKM akan lebih memahami lingkungan usahanya serta lebih memahami proses akuntansi dari usahanya sehingga pelaku UMKM akan lebih menggunakan informasi akuntansi untuk mengambil keputusan ekonomi dalam menentukan pilihan-pilihan diantara alternatif tindakan, untuk perencanaan strategis, pengawasan manajmen dan pengawasan operasional perusahaannya. Hanum (2013) menyatakan bahwa penggunaan informasi akuntansi dalam kebanyakan pengelolaan usaha kecil ditentukan oleh persepsi pengusaha kecil atas informasi akuntansi. Srivastava dan Lognathan (2016) menyatakan bhawa informasi akuntansi adalah bagian terpenting dalam sebuah organisasi (perusahaan), sehingga keberhasilan penerapan informasi akuntansi membutuhkan persepsi yang baik dari organisasi. Berdasarkan teori di atas maka Hipotesis dalam penelitian ini adalah

H1 : Persepsi pelaku UMKM berpengaruh Positif terhadap Penggunaan Informasi Akuntansi.

\section{Hubungan Pengetahuan Akuntansi Pelaku UMKM terhadap Penggunaan Informasi Akuntansi} Pengetahuan akuntansi adalah suatu pemahaman yang jelas akan apa yang dipandang sebagai fakta, kebenaran atau informasi mengenai proses pencatatan, pengelompokan, dan pengikhtisaran kejadian-kejadian ekonomi dalam bentuk yang teratur dan logis dengan tujuan menyajikan informasi keuangan yang dibutuhkan untuk pengambilan keputusan. Penggunaan Informasi Akuntansi merupakan proses, cara, pembuatan informasi akuntansi untuk pengambilan keputusan ekonomi dalam menentukan pilihan-pilihan diantara alternatif tindakan, untuk perencanaan strategis, pengawasan manajmen dan pengawasan operasional. Pengetahuan akuntansi yang tinggi akan menyebabkan penggunaan akan informasi akuntansi juga semakin tinggi, hal ini karena dengan semakin pahamnya pelaku UMKM atas fakta, kebenaran dan informasi menganai proses pencatatan, pengelompokan, dan pengikhtisaran kejadian-kejadian ekonomi akan menyebabkan penggunaan informasi akuntansi juga semakin tinggi sehingga mampu membantu dalam pengambilan keputusan. Setiawan (2012) memberikan hasil bahwa pengetahuan akuntansi menunjukkan bahwa tingkat pengetahuan akuntansi berada pada kategori baik dengan presentase rata-rata $83 \%$ pada UKM di Kota 69 | Jurnal Akuntansi, Ekonomi dan Manajemen Bisnis | Vol. 8 No.1, July 2020, 67-73 | E-ISSN: 2548-9836 
Depok. Linawati dan Restuti (2015) menunjukkan bahwa pengetahuan akuntansi berpengaruh positif terhadap informasi akuntansi pada UMKM di Kota Salatiga. Berdasarkan teori diatas maka Hipotesis kedua dalam penelitian ini adalah:

H2 : Pengetahuan Akuntansi Pelaku UMKM berpengaruh positif terhadap Penggunaan Informasi Akuntansi.

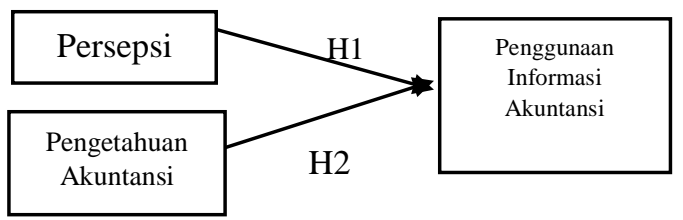

Gambar 1. Model Penelitian Sumber: Penulis

\section{Metodologi Penelitian \\ Teknik Pengumpulan Data}

Menurut Arikunto (2006) teknik pengumpulan data adalah cara-cara yang dapat digunakan oleh peneliti untuk mengumpulkan data. Cara menunjukan pada suatu yang abstrak, tidak dapat diwujudkan dalam benda yang kasat mata, tetapi hanya dapat dipertontonkan penggunanya. Tehnik pengumpulan data dalam penelitian ini adalah kuantitatif. Pada umumnya tekhnik pengumpulan data yang penulis pilih yaitu:

\section{a. Observasi}

Teknik observasi dilakukan dengan mengadakan pengamatan secara langsung terhadap obyek yang telah ditentukan, guna memperoleh data yang langsung dapat diambil oleh peneliti yaitu mengenai persepsi dan pengetahuan akuntansi pelaku UMKM dan seberapa besar pengaruhnya terhadap penggunaan informasi akuntansi. Sutrisno Hadi mengatakan bahwa, observasi merupakan suatu proses yang komples, suatu proses yang tersusun dari berbagai proses biologis dan psikologis. Maksud dari Sutrisno Hadi observasi yaitu proses dimana peneliti turun kelapangan untuk mengamati lingkungan yang akan ditelitinya.

b. Kuesioner (Angket)

Kuesioner merupakan teknik pengumpulan data yang dilakukan dengan cara memberi seperangkat pertanyaan atau pertanyaan tertulis kepada responden untuk dijawabnya. Kuesioner merupakan Teknik pengumpulan data yang efisien bila peneliti tahu dengan pasti variabel yang akan diukur dan tahu apa yang bisa diharapkan dari responden. Selain itu, kuesioner juga cocok digunakan bila jumlah responden cukup besar dan tersebar di wilayah yang luas. Kuesioner dapat berupa pertanyaan/pertanyaan tertutup atau terbuka, dapat diberikan kepada responden secara langsung atau dikirim melalui pos atau inetrenet. Selanjutnya jawaban responden dianalisis dengan motode Regresi Berganda yang diolah menggunakan bantuan SPSS. Populasi dalam penelitian ini adalah seluruh Pelaku UMKM sektor perdagangan di Kabupaten Gianyar yang berjumlah 17.143 unit usaha (Dinas UMKM Kab. Gianyar, 2017). Besarnya ukuran sampel yang harus diambil dalam suatu penelitian agar hasil penelitian tersebut dikatakan valid, berkaitan dengan tujuan pengambilan sampel (Sekaran, 2006). Untuk mendapatkan sampel yang bisa menggambarkan dan mencerminkan populasi dalam penelitian ini yang berjumlh 17.143 UMKM Perdagangan, maka penentuan jumlah sampel menggunakan rumus Slovin yaitu:

$$
\eta=\frac{N}{1+N \cdot e^{2}}
$$

Keterangan:

$\mathrm{n}=$ Jumlah Sampel

$\mathrm{N}=$ Jumlah Populasi

$\mathrm{e}=10 \%=0,10$

Berdasarkan rumus diatas maka dapat ditetapkan jumlah sampel minimal adalah sebagai berikut:

(dibulatkan)

$$
\eta=\frac{17 \cdot 143}{1+17 \cdot 143.0,01}=99,99=100
$$

Dari perhitungan rumus slovin tersebut digunakan sampel 100 UMKM sektor perdagangan di wilayah Kabupaten Gianyar. Tehnik sampling yang digunakan dalam penelitian ini dengan menggunakan simple random sampling, yaitu cara pemilihan sampel dengan pengambilan anggota sampel dari populasi dilakukan secara acak tanpa memperhatikan strata yang ada didalam suatu populasi tersebut. Cara ini dilakukan karena anggota populasi dianggap homogen (Sugiyono, 2009)

\section{Analisis regresi linear berganda}

Analisis regresi linear berganda adalah hubungan secara linear antara dua atau lebih variabel independen $\left(\mathrm{X}_{1}, \mathrm{X}_{2}\right.$ ) dengan variabel dependen (Y). Analisi ini untuk mengetahui arah hubungan antara variabel independen dengan variabel dependen apakah masingmasing variabel independen berhubungan positif atau negative dan untuk memprediksi nilai dari variabel dependen apabila nilai varaibel independen mengalami kenaikan atau penurunan.

Persamaan regresi untuk menguji hipotesis secara keseluruhan pada penelitian ini adalah sebagai berikut:

$\mathrm{Y}=\mathrm{a}+\mathrm{b}_{1} \mathrm{X}_{1}+\mathrm{b}_{2} \mathrm{X}_{2}+\varepsilon$

Keterangan:

$\mathrm{Y}=$ Penggunaan Informasi Akuntansi

$\alpha=$ Konstanta

$\mathrm{b}_{1}-\mathrm{b}_{2}=$ Koefisien Regresi

$\mathrm{X}_{1}=$ Persepsi Pemilik

$\mathrm{X}_{2}=$ Pengetahuan Akuntansi

$\varepsilon \quad=$ Faktor lain yang berpengaruh terhadap variabel 70 | Jurnal Akuntansi, Ekonomi dan Manajemen Bisnis | Vol. 8 No.1, July 2020, 67-73 | E-ISSN: 2548-9836 
terikat $(\mathrm{Y})$

\section{Pembahasan}

Hasil Penelitian

Pengujian Asumsi Klasik

Uji Asumsi klasik adalah persyaratan statistik yang harus dipenuhi pada analisis regresi linear berganda yang berbasis Ordinary Least Square (OLS). Uji ini dimaksudkan untuk mengetahui ada tidaknya pelanggaran asumsi klasik dalam model regresi supaya hasilnya BLUE atau Best Linear Unbiased Estimator (Ghozali, 2013). Uji yang akan dilakukan pada penelitian ini adalah uji Normalitas, Multikoliaritas, dan uji Heteroskedastisitas.

1. Uji Normalitas adalah uji statistik yang dilakukan untuk mengetahui bagaimana sebaran sebuah data. Uji normalitas yaitu suatu pengujian yang bertujuan untuk menguji apakah dalam model regresi, variabel pengganggu atau residual memiliki distribusi normal (Gozali, 2013). Residual model regresi yang baik adalah memiliki distribusi residual yang normal atau mendekati normal. Hasil uji normalitas disajikan dalam Tabel 1 .

Tabel 1

Uji Normalitas

\begin{tabular}{llr}
\hline & & $\begin{array}{r}\text { Unstandardi } \\
\text { zed } \\
\text { Residual }\end{array}$ \\
\hline $\mathrm{N}$ & Mean & 100 \\
Normal &, 0000000 \\
Parameters & Std. Deviation &, 18600113 \\
Most Extreme & Absolute &, 116 \\
Differences & Positive &, 050 \\
& Negative &,- 116 \\
Test Statistic & &, 077 \\
Asymp. Sig. (2-tailed) &, 130 \\
\hline a. Test distribution is Normal. & \\
b. Calculated from data. & \\
Sumber: Data primer yang diolah &
\end{tabular}

Berdasarkan Tabel 1 di atas maka diketahui nilai Asymp. Sig (2 tailed) pada dua model persamaan regresi mempunyai nilai yang lebih besar dari 0,05 . Jadi dapat disimpulkan bahwa model persamaan regresi tersebut telah memenuhi asumsi normalitas data.

2. Uji multikolonieritas bertujuan untuk menguji apakah dalam model regresi ditemukan adanya korelasi antar variabel independen. Model regresi yang baik seharusnya tidak terjadi korelasi di antara variabel independen dalam arti lain bebas dari gejala multikolonieritas. Variabel dalam model regresi tidak mengalami multikolonieritas apabila nilai tolerance $>$ 0,10 dan nilai $\mathrm{VIF}<10$.
Tabel 2

Uji Multikolinearitas

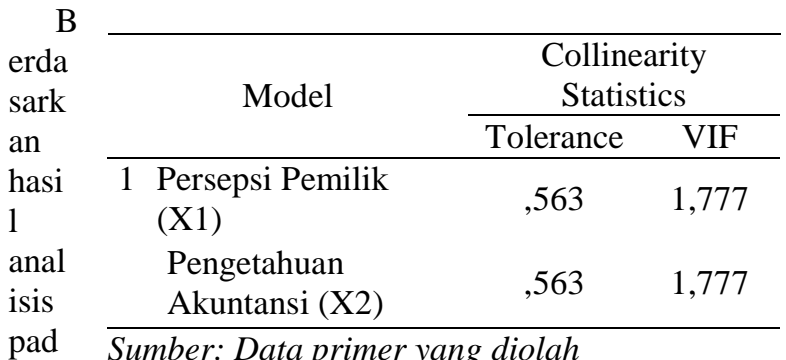
a

Tabel 2 dapat dilihat bahwa model regresi yang dipergunakan dalam penelitian ini tidak terdapat masalah multikolonieritas. Hal tersebut ditunjukkan dengan adanya nilai tolerance di antara variabelvariabel independen yang lebih besar dari 0,10 dan nilai VIF yang lebih kecil dari 10.

3. Uji heteroskedastisitas uji ini dimaksudkan untuk menguji apakah dalam model regresi terjadi ketidaksamaan variance dari residual satu pengamatan ke pengamatan yang lain. Model regresi yang baik adalah jika variance dari residual satu pengamatan ke pengamatan lain tetap atau homokedastisitas. Metode yang digunakan untuk mendeteksi heteroskedastisitas adalah dengan uji Glejser, dengan probabilitas signifikansinya di atas tingkat kepercayaan $(\alpha)=5 \%(0,05)$.

Tabel 3

Uji Heteroskedastisitas

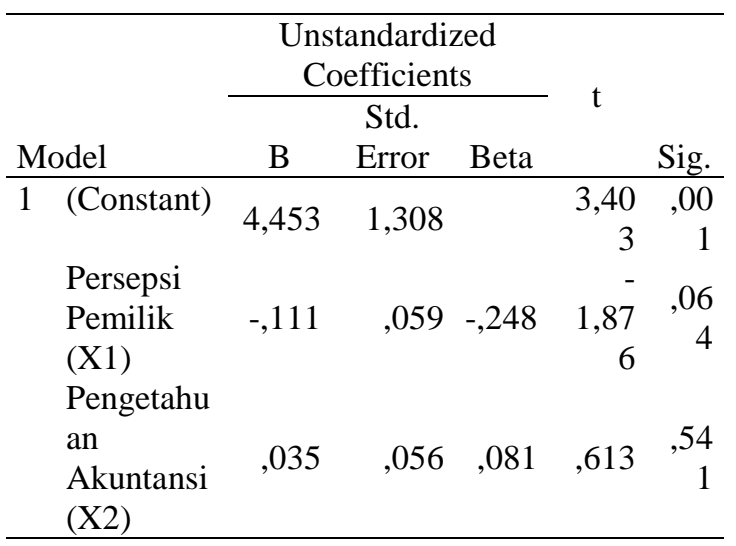

Sumber: Data primer yang diolah

Berdasarkan hasil analisis pada Tabel 3 dengan uji Glejser, mengindikasikan nilai probabilitas signifikansinya berada di atas tingkat kepercayaan 5\% $(0,05)$ yang berarti dapat disimpulkan bahwa variabelvariabel independen dalam penelitian tidak mengandung gejala heteroskedastisitas. 


\section{Analisis Regresi Linier Berganda}

Analisis regresi linier berganda digunakan dalam penelitian ini untuk menguji lebih dari satu variabel independen terhadap satu variabel dependen. Hasil uji regresi linier berganda dapat dilihat dari Tabel 4 berikut:

Tabel 4

Hasil Analisis Regresi Linier Berganda

\begin{tabular}{|c|c|c|c|c|c|}
\hline \multirow[b]{2}{*}{ Model } & \multicolumn{3}{|c|}{$\begin{array}{c}\text { Unstandardized } \\
\text { Coefficients }\end{array}$} & & \multirow[b]{2}{*}{ Sig. } \\
\hline & B & $\begin{array}{l}\text { Std. } \\
\text { Error }\end{array}$ & Beta & & \\
\hline 1 (Constant) & $\begin{array}{r}- \\
3,865\end{array}$ & 1,794 & & $-2,154$ & ,034 \\
\hline $\begin{array}{l}\text { Persepsi } \\
\text { Pemilik } \\
\text { (X1) }\end{array}$ & 779, & 081, & ,515 & 9,593 & ,000 \\
\hline $\begin{array}{l}\text { Pengetahua } \\
\mathrm{n} \\
\text { Akuntansi } \\
\text { (X2) }\end{array}$ & ,710 & 077, & 492, & 9,165 & ,000 \\
\hline
\end{tabular}

Sumber: Data primer yang diolah

Berdasarkan Tabel 4 di atas, maka persamaan analisis regresi linier bergandanya adalah sebagai berikut:

$\mathrm{Y}=-3,865+0,779 \mathrm{X}_{1}+0,710 \mathrm{X}_{2}$

a. Uji Goodness of Fit

Uji ini diperlukan untuk melihat apakah persamaan regresi yang akan digunakan untuk menguji hipotesis "fit" atau layak digunakan. Untuk menentukan "fit" atau tidaknya suatu persamaan regresi maka dapat dilihat dari nilai $\mathrm{R} 2, \mathrm{~F}$ dan nilai $\mathrm{t}$ berikut.

1) Koefisien Determinasi $\left(R^{2}\right)$

Besarnya nilai koefisien determinasi ( $R$ Square) sebesar 0,918 berarti penggunaan informasi akuntansi dapat dijelaskan oleh persepsi pemilik dan pengetahuan akuntansi sebesar $91,8 \%$, sedangkan sisanya yaitu $25,1 \%$ dijelaskan oleh variabel lain yang tidak diteliti.

\section{2) Uji F}

Sebelum dilakukan uji hipotesis, satu hal yang perlu diperhatikan adalah kelayakan model penelitian yang dilakukan dengan Uji $\mathrm{F}$ ( $F$ test) untuk mengetahui pengaruh variabel-variabel independen terhadap varaibel dependen. Jika hasil uji $\mathrm{F}$ adalah signifikansi berarti variabel independen mempengaruhi variabel dependen dan model layak digunakan sehingga pembuktian hipotesis bias dilanjutkan. Tabel 4 menunjukkan nilai $\mathrm{F}$ sebesar 30,832 dengan signifikansi sebesar 0,000 , ini berarti hasil uji $\mathrm{F}$ lebih kecil dari tingkat signifikansi yang ditetapkan $(\alpha=$ $0,05)$, sehingga dapat disimpulkan persepsi pemilik, dan pengetahuan akuntansi berpengaruh secara serempak pada penggunaan informasi akuntansi.

3) Uji t

Untuk mengetahui pengaruh pengaruh parsial apakah persepsi pemiliki dan pengetahuan akuntansi terhadap penggunaan informasi akuntansi, maka diuji dengan menggunakan Uji t.

- Tabel 4 menunjukkan nilai t untuk persepsi pemilik sebesar 3,295 dengan nilai signifikansi sebesar 0,00 ini berarti lebih kecil dari tingkat signifikansi yang ditetapkan $(\alpha=0,05)$, sehingga dapat disimpulkan persepsi pemilik berpengaruh terhadap penggunaan informasi akuntansi.

- Tabel 4 menunjukkan nilai $\mathrm{t}$ untuk pengetahuan akuntansi sebesar 3,338 dengan nilai signifikansi sebesar 0,00 ini berarti lebih kecil dari tingkat signifikansi yang ditetapkan $(\alpha=0,05)$, sehingga dapat disimpulkan pengetahuan akuntansi berpengaruh terhadap penggunaan informasi akuntansi.

b. Uji Hipotesis

Hipotesis 1 menyatakan bahwa persepsi pemilik berpengaruh terhadap penggunaan informasi akuntansi, Hipotesis 2 menyatakan bahwa pengetahuan akuntansi berpengaruh terhadap penggunaan informasi akuntansi.

- Nilai signifikansi (p-value) variabel persepsi pemilik sebesar $0,00(<5 \%)$ yang berarti tingkat keyakinan bahwa ukuran koperasi berpengaruh terhadap kualitas system pengandalian intern $>95 \%$. Dengan demikian hipotesis yang menyatakan bahwa persepsi pemilik berpengaruh terhadap penggunaan informasi akuntansi dapat diterima.

- Nilai signifikansi (p-value) variabel pengetahuan akuntansi sebesar $0,00(<5 \%)$ yang berarti tingkat keyakinan bahwa pengetahuan akuntansi berpengaruh terhadap penggunaan informasi akuntansi $>95 \%$. Dengan demikian hipotesis yang menyatakan bahwa pengetahuan akuntansi berpengaruh penggunaan informasi akuntansi dapat diterima.

\section{Pembahasan Hasil Penelitian}

Berdasarkan pada pengujian hipotesis yang telah dilakukan, maka berikut ini disajikan pembahasan dari hasil penelitian.

\section{Pengaruh persepsi pemilik terhadap penggunaan informasi akuntansi}

Hipotesis pertama (H1) menyatakan persepsi pemilik berpengaruh terhadap penggunaan informasi akuntansi. Hasil signifikansi uji t variabel persepsi pemilik sebesar 0,00 , ini berarti lebih kecil dari tingkat signifikansi yang ditetapkan $(\alpha=0,05)$, sehingga dapat disimpulkan bahwa H1 dapat diterima yaitu persepsi pemilik berpengaruh positif terhadap penggunaan informasi akuntansi. Hal ini sejalan dengan penelitian yang dilakukan oleh Srivastava dan Lognathan (2016) menyatakan bahwa informasi akuntansi adalah bagian terpenting dalam sebuah organisasi (perusahaan), 72 | Jurnal Akuntansi, Ekonomi dan Manajemen Bisnis | Vol. 8 No.1, July 2020, 67-73 | E-ISSN: 2548-9836 
sehingga keberhasilan penerapan informasi akuntansi membutuhkan persepsi yang baik.

\section{Pengaruh Pengetahuan Akuntansi terhadap penggunaan informasi akuntansi}

Hipotesis kedua (H2) menyatakan bahwa pengetahuan akuntansi berpengaruh positif terhadap penggunaan informasi akuntansi. Hasil signifikansi uji t variabel ukuran koperasi sebesar 0,00 , ini berarti lebih kecil dari tingkat signifikansi yang ditetapkan $(\alpha=$ 0,05), sehingga dapat disimpulkan bahwa $\mathrm{H} 2$ dapat diterima yaitu pengetahuan akuntansi berpengaruh positif terhadap penggunaan informasi akuntansi. Hal ini sejalan dengan penelitian yang dilakukan oleh Restuti (2015) menunjukkan bahwa pengetahuan akuntansi berpengaruh positif terhadap informasi akuntansi pada UMKM di Kota Salatiga.

\section{Kesimpulan dan saran \\ Simpulan}

Berdasarkan rumusan masalah, tujuan penelitian, landasan teori, hipotesis dan hasil penelitian, maka dapat disimpulkan sebagai berikut:

1. Persepsi Pemilik berpengaruh positif terhadap penggunaan informasi akuntansi. Hasil Uji hipotesis 1 menyebutkan bahwa $\mathrm{H} 1$ dapat diterima yaitu persepsi pemilik berpengaruh positif terhadap penggunaan informasi akuntansi.

2. Hasil Uji hipotesis 2 menyebutkan bahwa $\mathrm{H} 2$ dapat diterima yaitu pengetahuan akuntansi berpengaruh positif terhadap penggunaan informasi akuntansi.

\section{Saran}

Berdasarkan simpulan dan hasil analisis maka akan dikemukakan beberapa keterbatasan dan saran bagi penelitian selanjutnya sebagai berikut:

1. Penelitian selanjutnya disarankan dapat mengembangkan model dengan mencari faktorfaktor lain yang dianggap penting untuk analisis yang merupakan salah satu faktor determinasi potensial yang mempengaruhi penggunaan informasi akuntansi intern sepeerti tingkat pendidikan karyawan dan lain-lain.

2. Penelitian selanjutnya diharapkan dapat melakukan penelitian pada UMKM di kabupaten lainnya sehingga dapat membandingkan hasil yang diperoleh.

\section{DAFTAR PUSTAKA}

A. Arikunto, Suharsimi, Prosedur Penelitian: Suatu Pendekatan Praktik, Edisi Revisi VI, Jakarta: PT Rineka Cipta, 2006.

B. Belkaoui, A.R. (2000). Teori Akuntansi. Edisi Pertama, Salemba Empat, Jakarta.

C. Dinas Koperasi dan UKM Kab. Gianyar

D. Gozali, Imam. 2013. Aplikasi Analisis Multivariate dengan Program SPSS. Edisis Ketujuh. Semarang: Badan Penerbit Universitas Dipenogoro

E. Kurniawanysah. 2016. Penerapan Pencatatan Akuntansi Dan Penyusunan Laporan Keuangan Berdasarkan Sak Etap Pada Umkm Desa Gembongsari Kecamatan Kalipuro Kabupaten Banyuwangi.

jurnal.unej.ac.id/index.php/prosiding/article/view/ $3696 / 2885$

F. Linawati dan Restuti. 2015. Pengetahuan Akuntansi Pelaku Usaha Mikro, Kecil Dan Menengah (Umkm) Atas Penggunaan Informasi Akuntansi.

jurnal.unissula.ac.id/index.php/cbam/article/view/ $299 / 246$

G. Lognathan, S.P., MS. 2016. Impact of accounting information for management decision making". International Journal. Vol 2 (5): 171-174.

H. Madura, Jeff. (2001). Pengantar Bisnis Buku 2. Jakarta: Salemba Empat.

I. Mulyana, Deddy. 2001. Ilmu Komunikasi Suatu Pengantar.PT. Remaja Rosdakarya

J. Sekaran, Uma. (2006) "Research Methods For Busniess, 4 th Edition”. Salemba Empat. Jakarta

K. Setiawan. 2012. Kemajuann Teknologi dan Pengaruh Terhadap Kehidupan Remaja. Avievnet.blogspot.com. Diakses tanggal 5 Juli 2013.

L. Sugiyono. (2009). Metodelogi Penelitian Bisnis. Alfabeta, Badung.

M. Undang-Undang Nomor 20 Tahun 2008 Tentang Usaha Mikro, Kecil dan Menengah. 